\title{
THE EFFECTS OF LARGE DOSES OF FENTANYL AND FENTANYL WITH NITROUS OXIDE ON RENAL FUNCTION IN THE DOG
}

\author{
Arun V. Bibwai, Wen-Shin Liu, Theodore H. Stanley, Vanamala Bidwal, \\ Edward A. Loeser, and C. Lynn Shaw
}

FENTANYL in doses of $0.05-2.0 \mathrm{mg} / \mathrm{kg}$ and oxygen has recently been evaluated in dogs and suggested as an alternative anaesthetic technique to large doses of morphine and oxygen in critically ill patients. ${ }^{1}$ However, the renal effects of these doses of fentanyl are unknown. This study was conducted to determine the effects of $1 \mathrm{mg} / \mathrm{kg}$ of fentanyl with 50 per cent nitrous oxide in oxygen on renal function in the dog.

\section{METHoDs}

Fourteen unpremedicated male mongrel dogs weighing $15-23 \mathrm{~kg}$, were used in the experiment. All were given $2-3 \mathrm{mg} / \mathrm{kg}$ of sodium thiopentone and $2 \mathrm{mg} / \mathrm{kg}$ of succinylcholine intravenously. The trachea was intubated and the lungs were then ventilated with 100 per cent oxygen. Respirations were controlled with a volume limited respirator to keep $\mathrm{Pa}_{\mathrm{ro}_{2}}$ between $30-35$ torr as measured in aortic blood every 15-30 minutes. Basal anaesthesia was maintained with intermittent doses of sodium thiopentone 25-50 mg every 15-20 minutes throughout the experiment. Catheters were placed into the femoral artery (threaded into the thoracic aorta), into a vein in the forelimb and the urinary bladder. The aortic catheter was attached through an arterial pressure transducer to a central digital computer substation in the operating room. After dye dilution calibration the method of Warner, Gardner and Toronto² for analyzing the central aortic pulse-pressure curve was used for arterial blood pressure and cardiac output determinations during the control period and throughout the experiment.

Following catheter placement an infusion of 0.45 per cent sodium chloride was begun at a rate of $15-20 \mathrm{ml} / \mathrm{min}$ in order to establish a urine flow rate exceeding $5 \mathrm{ml} / \mathrm{min}$. When this had been achieved, loading doses of inulin and paraaminohippurate $(\mathrm{PAH})$ were given through the intravenous catheter. Constant inulin and PAH plasma concentrations of 25 and $2.5 \mathrm{mg}$ per cent respectively were maintained with an 8 to $12 \mathrm{ml} / \mathrm{min}$ drip of 0.22 per cent inulin and 0.15 per cent PAH in 0.45 per cent sodium chloride. The latter was administered at a rate which maintained the desired urine output above $5 \mathrm{ml} / \mathrm{min}$. After it had remained at this level for 30 minutes, the bladder was emptied and the first of two 15-minute control measurements was begun. At the end of each 15-minute collection period complete bladder emptying was ensured by supra-pubic pressure and instillation of $30 \mathrm{ml}$ of air into the bladder followed by its aspiration. During each collecting period urine

\footnotetext{
- From the Department of Anesthesiology, The University of Utah College of Medicine, 50
} North Medical Drive, Salt Lake City, Utah 84132.

Canad. Anaesth. Soc. J., vol. 23, no. 3, May 1976 
output was measured, a $6 \mathrm{ml}$ blood sample was obtained and both urine and blood specimens were analyzed for inulin, PAH and osmolarity. At the end of each collecting period, blood pressure and cardiac output were recorded.

Following the control measurements $1 \mathrm{mg} / \mathrm{kg}$ of fentanyl was given at a rate of $0.01 \mathrm{mg} / \mathrm{kg} / \mathrm{min}$. Timed urine and blood samples were obtained, as during the control period, after $0.1,0.25,0.5$ and $1.0 \mathrm{mg} / \mathrm{kg}$ of fentanyl had been administered. Following the administration of $1.0 \mathrm{mg} / \mathrm{kg}$ of fentanyl and with the fentanyl infusion continuing the inspired gases were changed to 50 per cent nitrous oxide in oxygen. Additional blood and urine sampling and blood pressure and cardiac output determinations were made 15 and 30 minutes following the start of nitrous oxide breathing.

Urine and blood samples were analyzed for osmolarity by means of an advanced osmometer. Inulin was measured in urine and blood by the method of Young and Raisz ${ }^{3}$ and PAH by the method of Brun. ${ }^{4}$ Inulin, PAH and free water clearances were determined using the standard clearance equation.

\section{RESULTS}

Mean values of all measured and calculated urine and blood parameters, systolic and diastolic blood pressure and cardiac output changes during the study periods appear in Tables I and II. Fentanyl caused an immediate and significant decrease in cardiac output and arterial blood pressure which was maintained throughout all subsequent study periods. Fentanyl also caused significant reductions in urine output and free water clearance and a marked increase in urine osmolarity but did

TABLE I

Cardiovascular Dynamics After LARGE DOSES OF FENTANYL

\begin{tabular}{|c|c|c|c|}
\hline & $\begin{array}{l}\text { Cardiac } \\
\text { output } \\
(\mathrm{L} / \mathrm{min})\end{array}$ & $\begin{array}{c}\text { Systolic } \\
\text { B.P. } \\
(\mathrm{mm} \mathrm{Hg})\end{array}$ & $\begin{array}{c}\text { Diastolic } \\
\text { B.P. } \\
(\mathrm{mm} \dot{\mathrm{H} g})\end{array}$ \\
\hline Control & $\begin{array}{r}3.4 \\
\pm 0.9\end{array}$ & $\begin{aligned} & 163 \\
\pm & 21\end{aligned}$ & $\begin{aligned} & 113 \\
\pm & 20\end{aligned}$ \\
\hline $\begin{array}{l}\text { Fentanyl } \\
0.1 \mathrm{mg} / \mathrm{kg}\end{array}$ & $\begin{array}{l}2.5^{*} \\
\pm 0.8\end{array}$ & $\begin{array}{l}153 \\
\pm 26\end{array}$ & $\begin{aligned} & 98 \dagger \\
\pm & 23\end{aligned}$ \\
\hline $\begin{array}{l}\text { Fentanyl } \\
0.25 \mathrm{mg} / \mathrm{kg}\end{array}$ & $\begin{aligned} & 2.1 \dagger \\
\pm & 1.0\end{aligned}$ & $\begin{aligned} & 151^{*} \\
\pm & 29\end{aligned}$ & $\begin{array}{r}97 \dagger \\
\pm 22\end{array}$ \\
\hline $\begin{array}{l}\text { Fentanyl } \\
0.5 \mathrm{mg} / \mathrm{kg}\end{array}$ & $\begin{aligned} & 2.3 \dagger \\
\pm & 0.7\end{aligned}$ & $\begin{aligned} & 149^{*} \\
\pm & 24\end{aligned}$ & $\begin{aligned} & 90 \dagger \\
\pm & 21\end{aligned}$ \\
\hline $\begin{array}{l}\text { Fentanyl } \\
1.0 \mathrm{mg} / \mathrm{kg}\end{array}$ & $\begin{aligned} & 2.2 \dagger \\
& \pm 0.8\end{aligned}$ & $\begin{array}{l}145 \dagger \\
\pm 30\end{array}$ & $\begin{aligned} & 88 \dagger \\
\pm & 21\end{aligned}$ \\
\hline $\begin{array}{l}50 \% \mathrm{~N}_{2} \mathrm{O} \\
15 \text { minutes }\end{array}$ & $\begin{array}{l}2.3 \dagger \\
\pm 0.7\end{array}$ & $\begin{array}{l}141 \dagger \\
\pm 26\end{array}$ & $\begin{aligned} & 89 \dagger \\
\pm & 24\end{aligned}$ \\
\hline $\begin{array}{l}50 \% \mathrm{~N}_{2} \mathrm{O} \\
30 \text { minutes }\end{array}$ & $\begin{aligned} & 2.5^{*} \\
\pm & 0.9\end{aligned}$ & $\begin{aligned} & 146 \dagger \\
\pm & 19\end{aligned}$ & $\begin{array}{r}92 \dagger \\
\pm 20\end{array}$ \\
\hline
\end{tabular}


TABLE II

Renal Function After Large Doses of Fentanyl

\begin{tabular}{|c|c|c|c|c|c|c|c|}
\hline & \multicolumn{4}{|c|}{ Clearance } & \multicolumn{3}{|c|}{ Osmolarity } \\
\hline & $\begin{array}{c}\text { Urine } \\
\text { volume } \\
(\mathrm{ml} / \mathrm{min})\end{array}$ & $\underset{(\mathrm{ml} / \mathrm{min})}{\mathrm{PAH}}$ & $\underset{(\mathrm{ml} / \mathrm{min})}{\text { Inulin }}$ & $\begin{array}{l}\text { Osmolar } \\
(\mathrm{ml} / \mathrm{min})\end{array}$ & $\begin{array}{c}\text { Free } \\
\text { water } \\
(\mathrm{ml} / \mathrm{min})\end{array}$ & $\underset{(\mathrm{mOsm} /}{\text { Urine }}$ & $\underset{\substack{\text { Plasma } \\
\text { kg) }}}{\text { Plasm }}$ \\
\hline Control & $\begin{array}{r}9.4 \\
\pm 1.9\end{array}$ & $\begin{aligned} & 158 \\
\pm & 67\end{aligned}$ & $\begin{array}{r}82 \\
\pm 17\end{array}$ & $\begin{array}{r}8.1 \\
\pm 2.0\end{array}$ & $\begin{array}{l}+1.3 \\
\pm 1.1\end{array}$ & $\begin{aligned} & 265 \\
\pm & 70\end{aligned}$ & 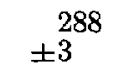 \\
\hline $\begin{array}{l}\text { Fentanyl } \\
0.1 \mathrm{mg} / \mathrm{kg}\end{array}$ & $\begin{array}{l}5.7^{*} \\
\pm 0.8\end{array}$ & $\begin{aligned} & 131 \\
+ & 54\end{aligned}$ & $\begin{array}{r}66 \\
\pm 20\end{array}$ & $\begin{array}{r}5.9 \\
\pm 2.1\end{array}$ & $\begin{array}{l}-0.2^{*} \\
\pm 0.9\end{array}$ & $\begin{array}{l}332 \\
+87\end{array}$ & $\begin{array}{l}283 \\
\pm 4\end{array}$ \\
\hline $\begin{array}{l}\text { Fentanyl } \\
0.25 \mathrm{mg} / \mathrm{kg}\end{array}$ & $\begin{aligned} & 3.1^{*} \\
\pm & 0.6\end{aligned}$ & $\begin{aligned} & 175 \\
\pm & 63\end{aligned}$ & $\begin{array}{r}91 \\
\pm 23\end{array}$ & $\begin{array}{r}5.6 \\
\pm 1.6\end{array}$ & $\begin{array}{l}-2.5 \dagger \\
\pm 1.2\end{array}$ & $\begin{aligned} & 628^{*} \\
\pm & 123\end{aligned}$ & 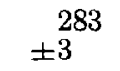 \\
\hline $\begin{array}{l}\text { Fentany } \\
0.5 \mathrm{mg} / \mathrm{kg}\end{array}$ & $\begin{array}{l}3.4^{*} \\
\pm 0.7\end{array}$ & $\begin{array}{l}199 \\
\pm 68\end{array}$ & $\begin{array}{r}96 \\
\pm 18\end{array}$ & $\begin{array}{r}7.2 \\
\pm 1.7\end{array}$ & $\begin{array}{l}-3.8 \dagger \\
\pm 1.0\end{array}$ & $\begin{array}{c}600^{*} \\
\pm 100\end{array}$ & $\begin{array}{l}283 \\
\pm 6\end{array}$ \\
\hline $\begin{array}{l}\text { Fentany } 1 \\
1.0 \mathrm{mg} / \mathrm{kg}\end{array}$ & 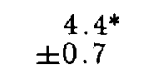 & $\begin{array}{l}193 \\
\pm 54\end{array}$ & $\begin{array}{r}91 \\
\pm 19\end{array}$ & $\begin{array}{r}7.3 \\
\pm 1.4\end{array}$ & $\begin{array}{l}-2.9 \dagger \\
\pm 1.1\end{array}$ & $\begin{aligned} & 507^{*} \\
\pm & 91\end{aligned}$ & 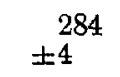 \\
\hline $\begin{array}{l}50 \% \mathrm{~N}_{2} \mathrm{O} \\
15 \text { minutes }\end{array}$ & $\begin{array}{l}5.0^{*} \\
\pm 0.8\end{array}$ & $\begin{aligned} & 225^{*} \\
\pm & 41\end{aligned}$ & $\begin{array}{r}83 \\
\pm 17\end{array}$ & $\begin{array}{r}6.6 \\
\pm 1.9\end{array}$ & $\begin{array}{l}-1.6^{*} \\
\pm 1.0\end{array}$ & $\begin{array}{l}442^{*} \ddagger \\
\pm 97\end{array}$ & $\begin{array}{l}288 \\
\pm 3\end{array}$ \\
\hline $\begin{array}{l}50 \% \mathrm{~N}_{2} \mathrm{O} \\
30 \text { minutes }\end{array}$ & $\begin{array}{r}6.3 \ddagger \\
\pm 0.7\end{array}$ & $\begin{array}{l}291 \dagger \ddagger \\
\pm 44\end{array}$ & $\begin{array}{l}110 \ddagger^{*} \\
\pm 19\end{array}$ & $\begin{array}{r}5.8 \\
\pm 1.8\end{array}$ & $\begin{array}{l}+0.5 \ddagger \\
\pm 0.9\end{array}$ & $\begin{array}{l}457 \ddagger \\
\pm 98\end{array}$ & $\begin{array}{l}286 \\
\pm 3\end{array}$ \\
\hline
\end{tabular}

* $\mathrm{P}<0.05$, Students paired $\mathrm{t}$-test when compared to control values.

$+\mathrm{P}<0.01$, Students paired t-test when compared to control values.

$\ddagger P<0.05$, Students paired t-test when compared to Fentanyl $1.0 \mathrm{mg} / \mathrm{kg}$ values.

not significantly change plasma osmolarity or $\mathrm{PAH}$, inulin or osmolar clearances. The addition of 50 per cent nitrous oxide to the inspired mixture produced no significant changes in cardiac output or arterial blood pressure but did result in significant increases in urine output, $\mathrm{PAH}$, inulin and free water clearances and a decrease in urine osmolarity. Nitrous oxide had no effect on osmolar clearance or plasma osmolarity.

\section{Discussion}

In a recent report Liu, Bidwai, Stanley and Isern-Amaral ${ }^{1}$ showed that enormous doses of fentanyl $(0.05-2.0 \mathrm{mg} / \mathrm{kg})$ produced significant reductions in heart rate, arterial blood pressure and cardiac output in dogs. These changes were not of great magnitude, however, and it was suggested that large doses of fentanyl and oxygen might be an attractive alternative to morphine and oxygen anaesthesia in critically ill patients. Critically ill patients frequently have impaired renal function and this could be made worse by an agent which reduces renal blood or plasma flow or stimulates antidiuretic hormone $(A D H)$ release. Therefore, this study was undertaken to investigate the renal effects of large doses of fentanyl in dogs and to compare them to prior findings with anaesthetic doses of morphine $(2 \mathrm{mg} / \mathrm{kg})$.

In these experiments cardiac output was reduced 26 and 38 per cent and systolic arterial blood pressure decreased 6 and 7 per cent after 0.1 and $0.25 \mathrm{mg} / \mathrm{kg}$ of fentanyl respectively. Additional fentanyl (up to $1.0 \mathrm{mg} / \mathrm{kg}$ ) did not produce further significant change in either output or arterial blood pressure. The changes in cardiovascular dynamics were associated with marked reductions in urine flow rate $(-39$ and -67 per cent) and free water clearance $(-115$ and -292 per cent $)$ 
after 0.1 and $0.25 \mathrm{mg} / \mathrm{kg}$ of fentanyl respectively and a significant increase in urine osmolarity ( +136 per cent) after $0.25 \mathrm{mg} / \mathrm{kg}$ of the drug. Additional fentanyl produced no further alterations in any of the renal parameters. No significant change was observed in PAH, inulin or osmolar clearances at any dose level of fentanyl although initial administration resulted in small decreases in all three of these clearances. These findings indicate that large doses of fentanyl do not significantly alter renal blood or plasma flow but suggest that they do stimulate ADH release. Whether this is due to direct central nervous system stimulation or secondary to a decrease in arterial blood pressure or cardiac output cannot be determined from our data.

In a recent report Bidwai, Stanley, Bloomer and Blatnick ${ }^{5}$ showed that $2 \mathrm{mg} / \mathrm{kg}$ of morphine significantly decreases arterial blood pressure and concomitantly produces marked reductions in urine flow rate $(-34$ per cent $)$ and free water clearance $(-142$ per cent) and an elevation in urine osmolarity ( +30 per cent) in dogs. As in this study inulin, $\mathrm{PAH}$ and osmolar clearances were unchanged by morphine. Comparison of these two studies demonstrates that $0.1-1.0 \mathrm{mg} / \mathrm{kg}$ of fentanyl does not differ from $2.0 \mathrm{mg} / \mathrm{kg}$ of morphine in its effects on renal function in the dog. It might be argued that this type of comparison is unfair because fentanyl is approximately 80-180 times as potent as morphine ${ }^{6-8}$ and, therefore, the doses used in this study were not equi-analgesic with $2 \mathrm{mg} / \mathrm{kg}$ of morphine. However, while fentanyl is indeed much more potent an analgesic than is morphine, it also has less amnesic properties than the latter. ${ }^{9,10}$ This means that significantly higher doses of fentanyl than those equi-analgesic to morphine will be required if fentanyl is to be used as the sole agent for anaesthesia. Although the dosage of fentanyl that will produce "complete anaesthesia", i.e. analgesia plus total amnesia has not been carefully evaluated either in man or the dog, Isern-Amara ${ }^{10}$ has found that $0.5 \mathrm{mg} / \mathrm{kg}$ of fentanyl is often required for adequate anaesthesia when that drug is used as the sole anaesthetic for patients with mitral valve stenosis undergoing valve replacement.

Addition of nitrous oxide to the inspired mixture of gases after $1.0 \mathrm{mg} / \mathrm{kg}$ of fentanyl produced no significant change in cardiac output and arterial blood pressure; significant elevations occurred in urine flow rate, inulin, PAH and free water clearances and there was a significant decrease in urine osmolarity. When nitrous oxide was added to anaesthesia in dogs who had received $2 \mathrm{mg} / \mathrm{kg}$ of morphine, Bidwai, et al. ${ }^{5}$ found no significant change in arterial pressure with a similar increase in free water clearance and decrease in urine osmolarity as was found in this study. These findings appear to indicate that nitrous oxide inhibits $\mathrm{ADH}$ release after large doses of fentanyl or morphine in the dog. They also suggest that addition of nitrous oxide after anaesthetic doses of morphine or fentanyl may preserve renal function better than utilization of the opiates by themselves. However, this applies to the dog and not in man, at least not where large doses of morphine are concerned. In a recent report Stanley, Gray, Bidwai and Lorden ${ }^{11}$ showed that, in contrast to the dog, the administration to man in the supine position of 60 per cent nitrous oxide after $2 \mathrm{mg} / \mathrm{kg}$ of morphine produced a 61 per cent decrease in urine flow rate with 34,27 and 74 per cent decreases in creatinine, osmolar and free water clearances respectively and an 82 per cent increase in urine osmolarity. While the 
mechanism producing these changes was not entirely clear, work by McDermott and Stanley ${ }^{12}$ has demonstrated that 50 per cent nitrous oxide after $2 \mathrm{mg} / \mathrm{kg}$ of morphine results in 44, 36 and 22 per cent decreases in cardiac output, stroke volume and mean arterial blood pressure and a 96 per cent increase in peripheral vascular resistance in man. These data plus those of Stanley et al. ${ }^{11}$ while not proving the point, nevertheless strongly suggest that impaired renal perfusion plays at least some part in the antidiuresis observed after nitrous oxide is added to anaesthetic doses of morphine in man. Interestingly, they also found that in well hydrated, supine, normocarbic and normotensive patients the slow administration of $2 \mathrm{mg} / \mathrm{kg}$ of morphine did not significantly alter any cardiac or renal function parameters studied. These results when combined with those of Bidwai et al. ${ }^{5}$ suggest that experiments in dogs while obviously important in evaluating a new anaesthetic technique, frequently yield results that are significantly different than those found in man.

The influence of anaesthetic doses of fentanyl on cardiac and renal function in man has not been extensively investigated and the effects of nitrous oxide after large doses of fentanyl has not been studied at all. What information is available ${ }^{10}$ suggests that, as with large doses of morphine, fentanyl does not significantly alter arterial blood pressure, cardiac output, heart rate or urine flow rate when given slowly and with adequate intravenous therapy and while respiration is supported with 100 per cent oxygen. If subsequently carefully performed renal function studies should demonstrate the benign influence of anaesthetic doses of the agent in man, then the technique of large doses of fentanyl plus oxygen may become an attractive technique for anaesthetizing critically ill patients for major operative procedures.

\section{SUMMARY}

Renal effects of large doses of fentanyl $(1 \mathrm{mg} / \mathrm{kg}$ ) were determined in 14 mongrel dogs before and after addition of 50 per cent nitrous oxide. Fentanyl significantly increased urine osmolarity and decreased urine output and free water clearance but did not change inulin or PAH clearances. The arterial blood pressure and cardiac output were significantly decreased after $0.1 \mathrm{mg} / \mathrm{kg}$ fentanyl and these changes were then maintained during the remainder of the study period. Addition of nitrous oxide produced no further changes in cardiac output and arterial blood pressure but did increase urine output, $\mathrm{PAH}$, inulin and free water clearances and decreased urine osmolarity. These data demonstrate that high doses of fentanyl have significant antidiuretic properties in the dog and these probably are related to the release of antidiuretic hormone. Our results also indicate that addition of nitrous oxide reverses fentanyl induced antidiuresis.

\section{RÉSUMÉ}

Le but du travail était de définir les effets d'une dose de $1 \mathrm{mg} / \mathrm{kg}$ de fentanyl et du fentanyl associé à 50 pour cent de protoxyde d'azote sur la fonction rénale du chien. Aux fins de cette recherche, l'on utilise 14 chiens mâles non prémédiqués.

Après la mise en place d'un cathéter de fort calibre, on a procédé à l'induction 
au moyen de thiopental de $\mathrm{Na}(2-3 \mathrm{mg} / \mathrm{kg})$ et de $2 \mathrm{mg} / \mathrm{kg}$ de succinylcholine pour faciliter l'intubation. Un cathéter fut mis en place dans la vessie, de même qu'un cathéter dans l'artère fémorale, de façon à mesurer la pression artérielle et le débit cardiaque par la méthode d'analyse par ordinateur de la courbe de pression aortique. Les animaux respiraient 100 pour cent d'oxygène, et leur ventilation etait contrôlée par un respirateur volumétrique pour maintenir une $\mathrm{pCO}_{2}$ artérielle entre $30-35$ torr.

On provoquait la diurèse en infusant $15-20 \mathrm{ml} / \mathrm{min}$ de solution 0.45 pour cent $\mathrm{NaCl}$, contenant suffisamment d'inuline et de PAH pour maintenir les concentrations plasmatiques à 25 et $2.5 \mathrm{mg}$ respectivement. La période de contrôle débutait lorsque la diurèse atteignait plus de $5 \mathrm{ml} / \mathrm{min}$. A la fin de chaque période on mesurait le volume urinaire, et on prélevait un échantillon de sang et d'urine pour détermination subséquente de linuline et du PAH. Après la période de contrôle, on donnait le fentanyl en dose de $1 \mathrm{mg} / \mathrm{kg}$, par doses fractionnées de $0.1 \mathrm{mg} / \mathrm{kg}$; et des échantillons de sang et d'urine étaient prélevés après $0.1,0.25,0.5$ et 1.0 $\mathrm{mg} / \mathrm{kg}$. A la suite de ces prélèvements, les gaz inspirés étaient changés pour 50 pour cent $\mathrm{N}_{2} \mathrm{O}, 50$ pour cent $\mathrm{O}_{2}$ et des échantillons d'urine et de sang étaient prélevés après 15 et $30 \mathrm{~min}$. A la fin de ces sept périodes d'étude, on a mesuré les clearances d'inuline, de PAH, d'eau libre et osmolaire, de même que la pression artérielle et le débit cardiaque.

Le fentanyl a provoqué une chute immédiate et significative du débit cardiaque et de la pression artérielle, qui s'est maintenue durant toutes les périodes d'étude. Le fentanyl a aussi provoqué une baisse significative de la diurèse et de la clearance d'eau libre de même qu'une augmentation marquée de l'osmolarité urinaire, mais sans modifier appréciablement l'osmolarité plasmatique ou les clearances de l'inuline, du $\mathrm{PAH}$, ou osmolaire. L'addition de 50 pour cent $\mathrm{N}_{2} \mathrm{O}$ n'a pas produit de modification significative du débit cardiaque ou de la pression artérielle mais a produit une augmentation significative de la diurèse, des différentes clearances, sauf la clearance osmolaire, ainsi qu'une baisse de l'osmolarité urinaire. L'addition de $\mathrm{N}_{2} \mathrm{O}$ n'a pas eu effet sur l'osmolarité plasmatique vu la clearance osmolaire.

Ces données démontrent que des doses élévées de fentanyl produisent chez le chien une antidiurèse significative tout en n'affectant pas les clearances de l'inuline ou du PAH; ces éléments sont en faveur d'une stimulation de la relâche de l'ADH. Nos résultats indiquent aussi que l'addition de $\mathrm{N}_{2} \mathrm{O}$ abolit l'antidiurèse induite par le fentanyl.

\section{REFERENCES}

1. Liv, W.-S., Bidwai, A.V., Stanley, T.H., \& Isern-Amaral, J. Cardiovascular dynamics after large doses of fentanyl and fentanyl plus nitrous oxide in dogs. Anesth. \& Analg. (In Press.)

2. Warner, H.R., Gardner, R.M., \& Toronto, A.R. Computer-based monitoring of cardiovascular functions in postoperative patients. Circulation 38: 68 (1968).

3. Young, M.K. \& Raisz, L.G. An anthrone procedure for determination of inulin in biological fluids. Proc. Soc. Exp. Biol. Med. 80: 771 (1952).

4. Brun, C. A rapid method for the determination of para-aminohippuric acid in kidney function tests. J. Lab. Clin. Med. 37: 955 (1951).

5. Bidwai, A.V., Stanley, T.H., Bloomer, H.A., \& Blatnick, R.A. Effects of anesthetic 
doses of morphine on renal function in the dog. Anesth. \& Analg. (Cleve.) 54: 357 (1975).

6. Gardocki, J.F. \& Yelnosky, J. A study of some of the pharmacologic actions of fentanyl citrate. Toxic. Appl. Pharmacol. 6: 48 (1964).

7. GoldeErG, A.H. \& PadcetT, C.H. Comparative effects of morphine and fentanyl on isolated heart muscle. Anesth. \& Analg. (Cleve.) 48: 978 (1969).

8. Stoelting, R.K., Gibbs, P.S., Creasser, C.W., \& Peterson, C. Hemodynamic and ventilatory responses to fentanyl, fentanyl-droperidol and nitrous oxide in patients with acquired valvular heart disease. Anesthesiology 42: 319 (1975).

9. Mostert, J.W., Trudnowski, R.J., Seniff, A.M., Moore, M.S., \& Case, R.W. Clinical comparison of fentanyl with meperidine. J. Clin. Pharmacol. 8: 382 (1968).

10. Isern-Amaral, J. (Personal Communication).

11. Stanley, T.H., Gray, N.H., Bidwai, A.V., \& London, R. The effects of high dose morphine plus nitrous oxide on urinary output in man. Canad. Anaesth. Soc. J. 21: 379 (1974).

12. McDermott, R.W. \& Stanley, T.H. The cardiovascular effects of low concentrations of nitrous oxide during morphine anesthesia. Anesthesiology $41: 89$ (1974). 